\title{
On the Term "Entrepreneur" and the Conceptualization of Entrepreneurship in the Literature of Classical Economics
}

\author{
Petur O. Jonsson ${ }^{1}$ \\ ${ }^{1}$ College of Business and Economics, Fayetteville State University, North Carolina, USA \\ Correspondence: Petur O. Jonsson, College of Business and Economics, Fayetteville State University, North \\ Carolina, USA. Tel: 1-910-672-1984. E-mail: pjonsson@uncfsu.edu
}

$\begin{array}{lc}\text { Received: July 16, } 2017 & \text { Accepted: August 10,2017 Online Published: September 15, } 2017 \\ \text { doi:10.5539/ijel.v7n6p16 } & \text { URL: http://doi.org/10.5539/ijel.v7n6p16 }\end{array}$

\begin{abstract}
Some of the literature on entrepreneurship suggests that the term entrepreneur was first introduced by either Cantillon or Say during the industrial revolution in the 18th and early 19th centuries. This article, by contrast, shows the term and the concept to be far older. Moreover, before the introduction of the term entrepreneur into English, the literature had a variety of other, and in some respect more nuanced, terms for entrepreneurs. Moreover, the article suggests that present-day scholars tend to misread both the pre-classical and the classical economists on the role of entrepreneurial initiative and creativity in the economy and that this has affected the conceptualization of the term in the current literature. In particular, Say's classical presentation of the entrepreneurial process was, in essence, dialectical and thus his ideas on entrepreneurship cannot be presented properly in the context of the modern-day equilibrium based models of today's economics.
\end{abstract}

Keywords: pre-classical economics, classical economics, Cantillon, Say, entrepreneur, entrepreneurship, dialectics

\section{Introduction}

As outlined by Jonsson (2014) the contemporary scholarly literature on entrepreneurs and entrepreneurship is not built on a unified theoretical framework. Instead, this literature is produced by different schools of thought, which not only ignore the work produced by each other, but which offer dissimilar definitions that are derived from mutually irreconcilable conceptual frameworks. In truth, when it comes to different schools of thought on entrepreneurship, each school has its own conceptual language. These different conceptual languages in turn both reflect and also structure how different scholars think about entrepreneurs and their role in the economy. The resulting definition debates are beyond the scope of this paper. Suffice it to say that, as explained in some detail by Jonsson (2014), some of the most widely cited definitions of entrepreneurs and entrepreneurship do not stand up to much logical scrutiny. Moreover, the introduction of the term entrepreneur from French into English seems to have imbued the underlying concept with a certain mystique. Certainly, a number of writers have suggested that the introduction of the term was associated with new ideas and a different way of thinking about the phenomena at hand.

Until recently, Webster's Online Dictionary (2015) suggested that the term entrepreneur was "first defined by... Richard Cantillon." This attribution is widespread in the literature. Perhaps it comes from Schumpeter (1954, p. 555), who wrote "Cantillon was, so far as I know, the first to use the term entrepreneur." A number of other writers have since echoed the claim that the terms entreprendre and entrepreneur originated with Cantillon. Thus Peneder (2009, p. 80) claims that "Cantillon coined the term "entreprendre", which indicated the general undertaking of a business." Baumol (2010, pp. 11-12) tells us that the "term "entrepreneur" was introduced by Richard Cantillon in the translation into French (suspected to have been carried out by Cantillon himself) of his great work". A different, but equally mistaken, attribution was made by Drucker (1985, p. 21) who suggested that "Say coined the term".

Yet, one only needs to check French dictionary sources to see that the origins of the terms entreprendre and entrepreneur in French predate the writings of Cantillon and Say. The French Centre National de Ressources Textuelles et Lexicales has a number of searchable historical dictionaries available online. One of these, Dictionnaire du Moyen Français 1330-1500 (available online at http://www.atilf.fr/dmf/) gives some examples of the word entrepreneur that date from the 15th century. More importantly, these terms were quite widely used 
in the French business and economics literature well before Cantillon or Say. Cantillon's Essai, purportedly translated from a lost English manuscript, was first published posthumously in French in 1755. And yet, as outlined in the next section of this paper, a simple word search of the Making of the Modern World database of historical economics documents reveals that the term entrepreneur had already been used in at least 123 different French books and pamphlets on commerce and political economy before that year. And, by the time Say's Traité appeared, the term had appeared in well over a thousand different works.

Some of the above-mentioned misattributions of the origins of the term entrepreneur implicitly posit that the concept of entrepreneurship was spawned by the industrial age. This view also suggests that entrepreneurship had to be named, outlined, and explained in a particular way before we could perceive the role it plays in the economy. Jonsson (2014) suggests that this perspective is largely derived from the fact that entrepreneurial creativity is a square peg in a round hole in the conceptual framework of modern economics. In the limiting context of formal choice theory, initiative and creativity seem exotic and outlandish. Thus economists who try to get a handle on entrepreneurial creativity tend to adopt a quasi-mystical and almost "Orientalist" perspective: seeing creative entrepreneurship as unique and exceptional rather than ubiquitous (see Jonsson, 2014). And, from that perspective, perhaps the notion that the concept of the entrepreneur was not discovered until the mid-eighteenth century may not seem all that peculiar.

Be that as it may, the bottom line is that neither Cantillon nor Say came up with the concept of the entrepreneur. Sure, both of them had some insight into the role of entrepreneurs in the economic system, but there can be little doubt that the concepts of enterprise and entrepreneurs are even older than written human history (see Landes, Mokyr, \& Baumol, 2012). To be sure, the pre-industrial writers whose works are preserved in the Making of the Modern World database of historical economics documents understood how new ventures call for initiative, creativity and risk taking. They did not elaborate on these things in quite the same way as Cantillon or Say, but not so much because they did not appreciate these things, but rather because they took them for granted. Life in pre-industrial economies was far more perilous than it is in our modern industrial or post-industrial world. The writers of earlier times knew in their bones that survival depended on initiative, creativity, stewardship and risk-taking. Besides, they were not constrained by an analytical context, such as our modern day general equilibrium framework, that downplays the very possibility of creative actions (see Barreto, 1989; Jonsson, 2014).

On the other hand, it is certainly true that the industrial revolution provided a variety of new opportunities for productive entrepreneurship. The industrial age also spawned improvements in communications, banking, and transportation. This period also provided better legal protection and enforcement of property rights. These, in turn, gave further incentives for productive efforts and exchange. But innovative entrepreneurship goes back a lot farther than the industrial age. It has been with us from the dawn of humanity (Landes, Mokyr, \& Baumol, 2012). Initiative and creativity, for good or ill, are a part of human nature and play a role in all human actions including consumption (see Jonsson, 1996). Our hunter-gatherer ancestors, Mother Theresa, Bernie Madoff and Steve Jobs alike, all exercised initiative and creativity in their endeavors. Sure, some people are more creative than others, and people do channel their creativity towards a variety of different ends, some productive and others destructive. After all, as explained by Baumol (2010, Chapter 9) innovative entrepreneurship is not about creating new products and services per se. Innovative entrepreneurship consists of "finding creative ways" to achieve one's objectives whatever they may be (Baumol, 2010, p. 155). As explained earlier by Baumol (1990), sometimes this calls for unproductive or even destructive actions. Sometimes people find creative ways to increase their status, wealth, or power without producing anything of value for others. Innovative entrepreneurs will create tradable new goods and services if, and only if, they have an incentive to channel their creative efforts in such pursuits. In truth, even today, some of the most creative and innovative efforts that we see anywhere are devoted to criminal enterprises. For example, as outlined by Jonsson (2009), much of internet crime is run by exceptionally creative people who consistently remain a step ahead of regulators, law enforcement and various internet security set ups.

The bottom line is that some periods and places provide extra incentives for entrepreneurial creativity to be channeled towards productive efforts. The industrial revolution and the 18th and early 19th centuries spawned cascades of productive entrepreneurial effort that changed the world. So, it makes sense for students of history to focus on entrepreneurship in this period. Yet, not only does the literature misrepresent the origins of the term entrepreneur, it often misrepresents what the term meant to the classical economists in general and to J. B Say in particular.

The thing is that 18 th and early 19 th century economic reasoning relied on a conceptual context that was very different from that of today's mainstream economics. Scholars of that time presented their ideas in a different 
way and they used a variety of different words to describe entrepreneurs and entrepreneurship. As a result, it is all too easy to dismiss their insights. It can be hard to understand arguments presented in an unfamiliar way. It is even harder when the arguments in question are also made in the context of an unfamiliar intellectual and analytical framework. If we wish to understand earlier writers then we must be careful not to conflate our vocabulary and world-view with that of theirs. As already noted, some present-day economists insist that awareness of entrepreneurship first turned up in the 18th century. This paper argues that it goes back a lot further. It is just that our reading of earlier writers, who did not rely on our terminology and our conceptual models, tends to be deficient.

The next section of this paper takes a closer look at the vocabulary of entrepreneurship leading up to the classical period in economics. It starts out with a closer look at the use of the terms entreprendre and entrepreneur in French prior to the publication of Cantillon's (1755) Essai. The section then goes on to demonstrate that different writers in English used a variety of different terms, including undertaker, adventurer, enterpriser, speculator and master, which in context corresponded quite closely to the French use of the term entrepreneur. Cantillon's original manuscript must have used one of these words, most likely either "undertaker" or "adventurer", which was then translated into the French as entrepreneur.

The third section then takes a closer look at how the classical economists, especially J. B. Say, thought about entrepreneurs, and about the role of entrepreneurship, in the economy. This section argues that Say's views on entrepreneurship are simply not compatible with today's mainstream general-equilibrium conceptual framework. So when we try to fit his arguments into this framework, his ideas inevitably get lost in translation. The very notion of steady-state general equilibrium would have been alien to Say. To him, each new innovation yielded new challenges and new opportunities that would in turn call for responses that would further change the status quo and necessitate additional reactions and adjustments. In this, Say's perspective on the entrepreneurial process is for all intents and purposes dialectical. Moreover, the entrepreneurial process that he envisioned was a process of discovery in the face of what we would now refer to as radical uncertainty.

\section{Entrepreneurs, Undertakers, Adventurers, Enterprisers, Speculators and Masters}

The following bar chart summarizes the number of different documents that were identified as containing the words entreprendre and entrepreneur in the MoME (Making of Modern Economy) database of historical economics documents through the year 1754 (the year before Cantillon's Essai was published) based on image searches of the original documents in the collection. Keep in mind that while the database is very extensive, it is not complete. Moreover, the image quality of some of the oldest books in the MoME database is either too poor, or else the fonts are not suitable for image searches, so that some documents which used the terms in question cannot be identified using this method. So we know that there are works from before 1755 that use these terms, which were not identified in this search and thus were not included in the chart below. For example, the earliest use of the word entrepreneur that I was able to find by scouring the MoME database is Hennequin (1595), who used the word to describe independent contractors who undertook projects (see, for example, Hennequin, 1595, p. 127), but due to an uneven font and poor image quality this work was not identified in the word search that was used to create Figure 1, below, and hence is not included. Even so, the image search still identified a total of 705 different books and pamphlets which used the term entreprendre to describe entrepreneurship and entrepreneurial activity, along with 123 different works which used the term entrepreneur, before Cantillon's Essai was published in 1755. 


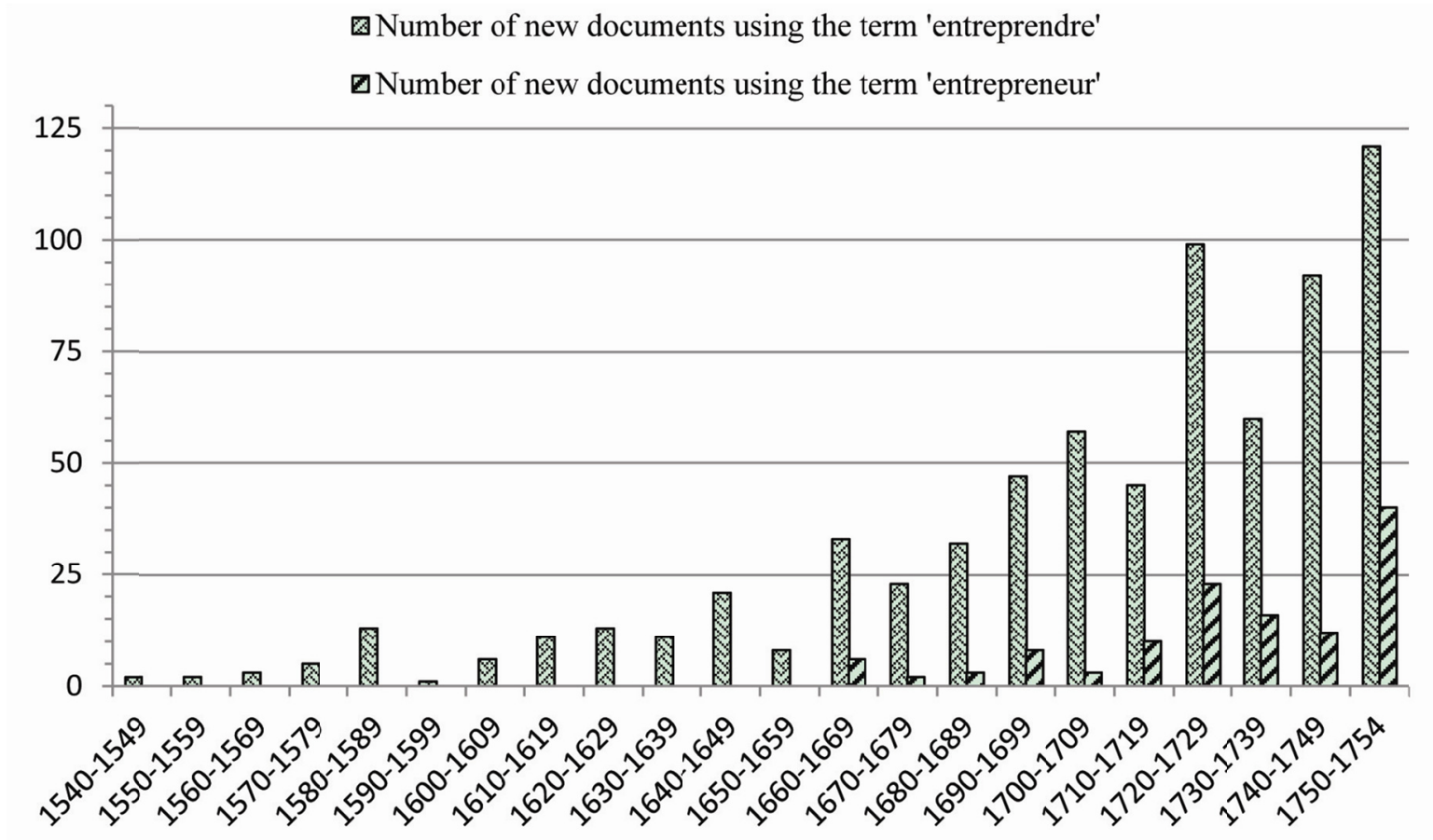

Figure 1. Books and pamphlets in the MoME database which used the words "entrepreneur" and "entreprendre" prior to the posthumous publication of Cantillon's Essai in 1755

In French the verb entreprendre (also emprendre) means "to undertake" some task, or charge, or mission. Similarly, the nouns entrepreneur or entrepreneuse (feminine) originally refer to a person who takes on the activity in question. The term was typically used to described contractors who would contract to build buildings, fortifications, bridges or city pavements, or who would contract to clear land, or to provide food, etc. At the time, the most commonly used equivalent word in English was "undertaker". It was only later that that word, undertaker, came to denote someone engaged strictly in the funeral business. Consider some early examples:

In an undated pamphlet that may have been published sometime in the late 16th century, Badeslate (n. d.) wrote about undertakers who contracted to make rivers navigable and noted that "the Undertaker of such sort of works ought to be a good practical Surveyor, and be able to take his own Levels, and to draw his own maps" (Badeslade, n. d., image 17 of 22). Similarly, a pamphlet from 1608 outlined the duties and rights of the "vndertakers" of escheated lands, who contracted to manage these lands for a portion of the proceeds that they could generate (England \& Wales, 1608). Parker (1642), using the term in a similar fashion, wrote about situations in which "undertakers" were coerced, by local authorities, to engage in various projects and practices.

At about the same time, others wrote about undertakers assuming risk, responding to incentives, initiating new ventures, innovating, and in some cases practicing rent seeking; all actions which we now associate with entrepreneurs. Consider the following examples: Potter (1650, image no. 6) wrote about "difficulty and dangers to the Undertakers" and situations under which "Undertakers.... shall have much more reason to employ the utmost of their Stock and credit, in a way of Trade, than now they have."(Potter, 1650, p. 26) In a similar sense, Darell (1651, p. 36) wrote about trade opportunities that were ignored by "Inconsiderate English and present undertakers". Violet (1653, p. 6), in writing about how changing farm practices would create new opportunities that might attract profit seekers, put it thus: “...upon new alteration in the model of the Farm, there might com [sic] new undertakers". Hartlib $(1655$, p. 49) worried about "undertakers, that are apt to promise much upon the score of hope and fancies". A pamphlet from 1662, complained about "undertakers" set on producing "nothing but Tobacco, a new invented needless Weed" (Anonymous, 1662, p. 3). Others talked about useful innovations created by undertakers, for example Gerbier $(1663$, p. 92), who wrote about a new kind of long-lasting pavement that "undertakers ...have industriously invented." In a similar vein, a number of writers also wrote about the role of undertakers in the economy of the new world. Thus Hartlib (1655) worried that the benefits from colonies and colonial trade would mostly be on the form of profits for "undertakers" (1655, Part 2, p. 13). Gorges wrote about the role of undertakers in attracting a variety of religious minorities to America. Specifically, based on rights and 
patents granted them by the crown, "the undertakers went on so prosperously, that in a short while great numbers resorted of all sorts of people" (Gorges, 1658, p. 25).

By the time that Adam Smith (1776) wrote his Wealth of Nations, the term undertaker in this sense was well established and had a long history. So this was the word used by Smith. When the Wealth of Nations was translated into French, this term, undertaker, was in turn translated into French as entrepreneur. For example, where Smith (1776, Chapter VI, p. 57) mentions "the profits of the undertaker of the work who hazards his stock in this adventure" this was translated into French as "les profits de l'entrepreneur qui a risqué ses fonds à cet emploi" (Smith, 1778, Chapter VI, p. 128).

Before adoption of the term entrepreneur into English, another set of widely used terms, right along with undertake and undertaker, were "adventure" and "adventurer". In Latin, adventura refers to something "about to happen". Adventurers then ventured risky undertakings hoping to bring some desired result. As the saying goes: nothing ventured, nothing gained. Plat $(1594$, p. 29$)$ put it thus: "It is a small aduenture to hazarde a shilling to gaine a pounde". Thus Chamberlen $(1649$, p. 44) refers to "Adventurers, of all Moneys, lent upon the Bank"; Belcamp (1651, p. 7) refers to "every Adventurer invested in actual possession of his respective proportions of Lands"; Smith (1661, p. 20) refers to "Adventurers" who invest in "Fishing for Herring, Ling and Cod"; and Howell (1678, p. 369) refers to a captain with a financial stake as "a co-adventurer in that expedition."

When Bushell (1642, image 25) wrote about "such persons as are or shall be Undertakers and Adventurers", he was therefore writing about those who took on both responsibility and also significant risk for the venture at hand. Similarly, merchants who engaged in risky trades, especially import and export, were referred to as merchant adventurers. This was reflected in the names of the trading guild cartels of the 15th through the 17th centuries: for example the Company of Merchant Adventurers of London that was chartered by Henry IV in the year 1407. As Malynes (1656, p. 150) put it "the adventurer in Lotaries incurreth lesse danger than Merchants do in the course of trade, especially in Assurances".

The term adventure was particularly reserved for risky business ventures. Seventeenth century writers were quite explicit that adventures were motivated by profit and hence that adventurers would avoid ventures that had little chance of yielding profit. In 1549 William Stafford wrote a famous essay using his initials, W.S. (later falsely attributed to William Shakespeare and republished in 1751) that contained the following screed against extortive taxation and regulations:

Take these rewards from them, and go about to compel them by lawes thereto, what man wil plough or dig the ground or exercise any manuall arte wherein is any paine: or who will adventure (italics added) over seas for any merchandise, or use any facultie wherein any peril or daunger should be no more then [sic] his that fits still. (Stafford, 1581; 1751)

Similarly, White (1630, p. 21), in discussing why linen was rarely made in England, noted that this was simply based on profit expectations:

If we adventure (italics added) the making of linnen cloth, other soiles are so much fitter to produce the materialls for that worke, their labour is so much cheaper, the hindering of Commerce in trade is likely to be so great, that the undertakers of this worke would in all probability be soone discouraged.

It was also in this context that Robartes $(1613$, p. 94) had suggested that merchants, tradesmen and husbandmen, who were risk-takers, should be allowed to deduct expenses from failed ventures before tithing, "as their charge and adventure (italics added) falleth out to." The need to compensate for risk was also the bone of contention in the usury debates of the 17th century. Thus Purser (1634. p. 84) argued that interest had to be paid to compensate lenders for "the hazard and adventure of loosing [sic] the principal", while Bolton (1637, p. 65) retorted that "Usury is masked under the Habit of hazard, and adventure".

The following bar chart summarizes the results of an image search for the two terms, undertaker and adventurer in the MoME database for the years 1640-1799. 


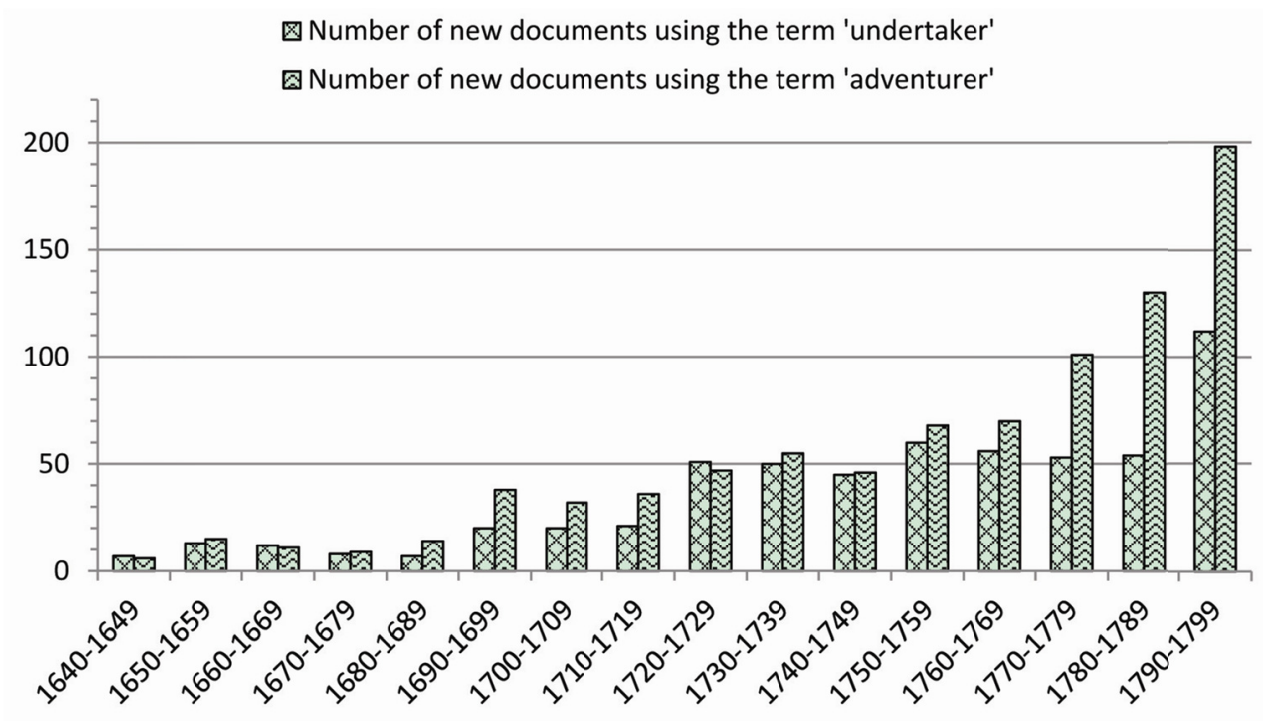

Figure 2. The number of MoME documents published 1640-1799, which were identified as using the terms "undertaker" and "adventurer" to describe entrepreneurs

Consider now how Cantillon's entrepreneur fits in with all of this. First, we should note that there are a number of unresolved questions about the origins of Cantillon's Essai. While the 1755 title page claims that the Essai was translated into French from English, the supposed original English manuscript has been completely lost. In this context, there have even been some suggestions that the work may actually not have been translated, but rather originally written in French, and conceivably not even by Cantillon (see Jevons, 1881). However, since these speculations are not backed by any hard evidence, let us for now assume the cover page to be correct and that the Essai was originally written in English by Cantillon and only later translated into French. The question we must then ask is: what was the original English word that Cantillon used which was translated into the French as entrepreneur? Obviously, we cannot know for certain, but it is clear that Cantillon's (1755) entrepreneur is very much akin to the undertakers and adventurers in the prior English literature discussed above. So it seems probable that Cantillon originally used one of these terms: either "undertaker" or "adventurer". When Higgs (see Cantillon, 1931) later translated the French version back into English, he used the word undertaker, but the word adventurer would certainly also fit the bill.

The point is that there was nothing new in the use of the word entrepreneur in Cantillon's Essai. Certainly, the early promoters and advocates of Cantillon's ideas did not see his entrepreneur as a new idea. Jevons (1881) and Higgs (1891 and 1892) were the English economists most responsible for the renewed interest in Cantillon's ideas in the late nineteenth century. Both of them gave detailed accounts of all the insights and novelties that they and others had gleaned from Cantillon's writing. Yet neither one of them even mentions the entrepreneur (or undertaker) as a new idea. In fact, while Jevons (1881) summarized most of the Essai chapter by chapter, outlining all the new ideas in each one, he simply skips over Chapter 13, the chapter in which Cantillon describes and focuses on the entrepreneur.

Cantillon's primary focus was on the circulation of trade and commerce in the context of a simple economy in which all value is derived from land. As Cantillon saw it the land was the source of both food and clothing and thus all trade in the economy was based on necessities created by agriculture. According to Cantillon, this meant that everyone was dependent on landowners for their subsistence and that the produce of land provided a foundation upon which all other economic activity rested. The question he then asked was: how are the necessities of life distributed to those who do not own any land. In Cantillon's view there were three kinds of actors in the economy: first were the landowners who controlled the sources of food and clothing, next were those who worked for others for a fixed salary, and finally there were the entrepreneurs, everyone who somehow scrounged for a living without relying on fixed wages. As Saucier's later translation put it: "All the others are entrepreneurs, whether they are set up with a capital to conduct their enterprise, or are entrepreneurs of their own labor without capital, and they may be regarded as living at uncertainty; even the beggars and the robbers are entrepreneurs of this class." (Cantillon 2010, p. 76) (Note 1) 
In short, everyone whose livelihood depended on speculative risk taking was an entrepreneur. Even so, Cantillon did not explicitly discuss the creative aspects of entrepreneurship that we now identify with Schumpeter. Cantillon merely focused on circulation and trade which he believed were driven by arbitrage opportunities. Thus he focused on the role of entrepreneurs in steering speculative and risky arbitrage and moving already known and existing products and services to the places where these fetched the greatest value. Cantillon's entrepreneur thus had to rely on some of the opportunity alertness later described by Kirzner (1997 and 1999), but merely in terms of trade, not in terms of innovations. It is here that J.B. Say's discussion on entrepreneurs goes beyond Cantillon. Say explicitly stressed the role of entrepreneurs in changing the nature of products and processes and thereby in transforming and disrupting the economy. This foreshadowed Schumpeter's creative destruction and there is little doubt that Say's discussion of the entrepreneur imbued the very term with new meaning.

Given the widespread use of the words undertaker and adventurer, it should not be surprising that, as the 19th century translator of Say's Traité saw it, these were his two choices for translating the word entrepreneur into English. Prinsep, the translator, discusses this in a footnote in the first American Edition of his translation (Say, 1821, p. 25):

The term entrepreneur is difficult to render in English; the corresponding word, undertaker, being already appropriated to a limited sense. It signifies the master-manufacturer in manufacture, the farmer in agriculture, and the merchant in commerce; and generally in all three branches, the person who takes upon himself the immediate responsibility, risk, and conduct of a concern of industry, whether upon his own or a borrowed capital. For want of a better word, it will be rendered into English by the term adventurer.

Clearly, Prinsep did not feel completely at ease with either of the terms, undertaker or adventurer; his unease likely derived from Say's nuanced discussion of the role of entrepreneurs in the economy. Even so, we should reiterate that Say's discussion of the entrepreneur was based more on the writings of Adam Smith than the writings of Cantillon. After all, in the earlier translation of Smith's (1778-9) Wealth of Nations into French, Smith's "undertaker" became entrepreneur. There is no question that Say was well familiar with this particular translation. According to Say himself, no other work influenced him more than did Recherches sur la nature et les causes de la richesse des nations, and no author influenced him more than Smith (1778-9) did: "I revere Adam Smith - he is my master. When I took the first steps in political economy... he shewed me the true path." (Note 2) (Say, 1821, p. 21). In fact, by my count, Smith is mentioned over a hundred times in Say's (1803) Traité.

In any case, although undertaker and adventurer were the most commonly used English words for entrepreneur, there were other words available. Thus, Samuel Johnson's 1755 dictionary has the following entry: "Enterpriser. n.s. [from enterprise.] A man of enterprise, one who undertakes great things; one who engages himself in important and dangerous designs." Granted, this word was not commonly used, but it still pops up in a few places. For example, it is used along with the word undertaker in a translation of Turgot's Réflexions into English that was included as part of the 4th edition of Smith's Wealth of Nations (Smith, 1801, p. 63). Supposedly Turgot's Réflexions was "the germe from which Mr. Adam Smith formed his excellent treatise on the Wealth of Nations" (Smith, 1801, p. 2). The word enterpriser is also used as the translation of entrepreneur in one of the two different translations of Say's Letters to Malthus (Say, 1821) that were published in 1821.

Another word that was occasionally used in translating entrepreneur into English was "speculator". This term was used by Richter (Say, 1821) in his translation of Say's Letters to Malthus, presumably because the context emphasized the speculative risk taking role of entrepreneurs. Consider for example: "C'est l'entrepreneur que tous les risques atteignent" (Say, 1820, p. 29) Richter translated this into English as "All the risks attach to the speculator". (Say, 1821, p. 14)

Finally it should be noted that Ramsay (1836, p. 82), in discussing returns to different factors of production, talks about factor incomes as returns to the "labourer, master, capitalist and landlord". In a footnote, he makes it explicit that he means the word "master" to be equivalent to entrepreneur in French.

In contrast with the generic designation "men of business" used by a number of writers (for example Mun, 1664, image 7; Petty, 1683, p. 39; Dufour, 1685, p. 109), each of the terms undertaker, adventurer, enterpriser, speculator and master emphasizes some particularly entrepreneurial aspect of economic behavior. While the writers who used these terms may not have anticipated our later musings on entrepreneurship, they clearly understood the importance of initiative, responsibility, stewardship and risk taking in seeking out new opportunities and in starting new ventures. Their vocabulary may have been different from ours, but they still thought about the role of entrepreneurs in the entrepreneurial process. 


\section{Say's Entrepreneur}

As we have seen, neither Cantillon nor Say coined the term entrepreneur and neither of them was the first to conceive of entrepreneurs as people who initiate and run new ventures. Even so, both of them had things to say about the role of entrepreneurs in the economy. Not about the existence of entrepreneurship per se, but rather about the particular role entrepreneurs play in economic coordination and in what we now think of as the circular flow of income. So, those who focus on Cantillon and Say are right that the two helped develop the functional concept of entrepreneurship. Even so, misconceptions about the place of entrepreneurs in classical economics persist. In particular, Say's arguments are often taken out of their original context and misconstrued (see Jonsson 1995 and 1997). Some writers even try to interpret Say as if his arguments had been made in the context of 20th century economic theory. The following quote represents a commonly held view of Say:

Say regarded the entrepreneur as a manager of a firm; an input in the production process. The entrepreneur acts in the static world of equilibrium, where he assesses the most favorable economic opportunities. The payoff to the entrepreneur is not profits arising from risk-bearing but instead a wage accruing to a scarce type of labor. Say highlighted, in that way, that the role of the entrepreneur is separated from that of the capitalist. (Iversen et al., 2008, p. 5)

At best, this represents a misreading. To see why this is so, let us consider Say's ideas a bit further. First consider who is an entrepreneur. In Say's view virtually everyone who participated in exchange had to be an entrepreneur in the sense that they had to have initiative and they also had to gather different resources in order to participate. To Say, the entrepreneur was the actor or agent who made economic decisions in the face of uncertainty. In any venture some might contribute more capital than others, but all still had to contribute some, and all had to be entrepreneurial. This is an important, but generally overlooked, point made by Say. Even if you just sell your own labor, first you must create conditions for that sale to be possible. As Say saw it, this calls both for some entrepreneurial initiative and also some capital commitment on your part. Workmen had to bring tools, or at a minimum had to be clothed before they could successfully sell their labor. Say expounds on this in the 5th Chapter of the 4th edition of the Traité. He specifically explains how this is true of common laborers, bricklayers, journeyman tailors and knife grinders. Most participants in any given enterprise play multiple roles. This is Say's point when he notes (Say, 1821, p. 25): "A man who cultivates his own garden at his own expense, is at once the possessor of land, capital, and industry, and exclusively enjoys the profits of proprietor, capitalist and labourer." (Note 3) The idea here is not, contrary to the Iversen et al. quote above, that the entrepreneur is separated from the capitalist, but rather that we are entrepreneurs and also capitalists at the same time!

To participate in the economy, we all have to be alert for entrepreneurial opportunities and we have to adjust and adapt as new opportunities become available. Say believed that entrepreneurial initiatives were constantly changing the world. To be successful we needed to both contribute to and respond to the changes as they happened. He gives multiple examples of this in various parts of the Traité. His ideas on this were clearly tied to his views on markets, as he specifically and explicitly noted that innovations in any industry tend to create opportunities and challenges not just in that industry, but also in others since all markets are related through trade. In Chapter 6 of the Traité, he discusses this in the context of how the use of glass and new building materials changed the construction industry and called for new skills and occupations. Alert entrepreneurs will respond to innovations that affect them, or as Say put it: "the cultivator, the manufacturer, the trader, make it their business to turn to profit the knowledge already acquired" (Say, 1821, p. 33) (Note 4) by science and experience. And, as they do so, they will learn more and make additional adjustments based on trial and error as they "experiment, which is always attended with more or less of risk, and does not always indemnify the adventurer, whose profit, even when successful, is moderated by competition" (Say, 1821, p. 34) (Note 5)

Let us briefly consider how this relates to Say's arguments on markets. As explained by Jonsson (1995 and 1997), Say started out with the simple truism that voluntary trade has to be bilateral in the sense that each trading partner must be able to offer the other something of value. This is what Say meant when he noted that "the value we can buy is equal to the value we can produce." (Say, 1821, p. 3) In this context, he then focused on both coordination and on coordination failures. He concluded that whenever an entrepreneur is unable to sell his goods this must be due either (1) to the entrepreneur's failure to produce value that others would want to trade for, or else (2) a failure by potential trading partners to create something worth trading for.

Say envisioned entrepreneurs operating in an environment characterized by what we would now call radical uncertainty. The very notion of "equilibrium" would have seemed strange to him and his contemporaries. Rather than envisioning some sort of static full information equilibrium, Say saw entrepreneurs as constantly looking for and responding to vent, or market openings. These market openings and trading opportunities would depend 
on the actions of potential trading partners. Moreover, the very act of trading would in turn create new opportunities and/or challenges that would in turn elicit new responses. Thus the volume, the direction, and the nature of trade would be constantly changing and evolving. Say's detailed explication on the evolution of European trade with America (Say, 1821, pp. 53-57) illustrates this quite well. In short, as he saw it, what the Europeans were able to export depended on the needs of the Americans and also on what the Americans had available to trade in return. Next, as trade ensued, the very process of trade changed what the Americans themselves needed to import, what they decided to produce themselves, and what they would be able to offer in trade later. Thus, over time, the nature of trade between the continents changed in a variety of different ways, and as Say saw it, was bound to keep changing over time.

In seeking opportunities, entrepreneurs took risks and in the process they often made mistakes. Say was very clear that the returns to the entrepreneur (or "speculator" in Richter's translation) depended on risk taking:

The profit of the speculator, on whose account this operation has been effected, deducting the interest of the capital which he may have employed represents the remuneration for his time and talents; that is to say his own productive services employed in his own behalf. If his abilities be great, and his calculations well made, his profit will be considerable. If instead he evinces inexperience in his affairs, he may gain nothing; he may very probably be a loser. All the risks attach to the speculator; but on the other hand he takes the advantage of all the favorable chances. (Say, 1821, p. 14) (Note 6)

Sure, Say notes that the returns to the entrepreneur represent return on productive services. But, contrary to Iversen et al. (2008, p. 5), he is definitely not saying that the returns to the entrepreneur are simply wages for a particular type of labor that have nothing to do with risk. Say was quite clear that entrepreneurship involved risk taking and that a variety of unexpected events might throw entrepreneurs for a loop. And, whenever one entrepreneur fails, this in turn affects the entrepreneur's potential trading partners. Sometimes this can create ripple effects that go across the entire economy and create series of gluts. This was Say's explanation for recessions. Amongst the things that can create recessions Say (1821, pp. 122-123) listed unexpected wars, trade restrictions, oppressive and arbitrary duties and taxes, speculative bubbles and inflationary deterioration of the currency.

In truth, Say's conception of the entrepreneurial process seems dialectical. Not really in the Hegelian or Marxist sense, but in the original sense of a dialog made up of a sequence of arguments and counterarguments. Each new technology or idea that generates new products or services embodies an argument that entrepreneurs must respond to. Their responses can in turn be conceived as counterarguments which call for further responses. As Say saw it, new technologies, new ideas and actions, new products and new processes change the status quo. This in turn generates new opportunities or challenges to be met by other new ideas, actions, products and processes. Each innovation thus creates either an amplifying response or a countercheck. Just consider Say's discussion on how new ideas led paper manufacturers to experiment with fibers which in turn yielded better paper that in turn facilitated easier and cheaper printing which in turn affected the dissemination of ideas that affected all industries (Say, 1821, pp. 31-32). After discussing a number of such examples Say concluded that many innovations benefit, not just the industry that initiates them, but also other industries and society at large. Say then makes the point that these innovations have what we today would refer to as positive externalities and public goods characteristics. As a result, there will be free-rider problems in the provision of innovation and therefore the search for knowledge and new ideas should to some extent be supported by public funds (Say, 1821b, pp. 33-36). His discussion of how innovations and new products can displace labor and obliterate old industries (Say, 1821, pp. 38-41) also foreshadow some of Schumpeter's later ideas on creative destruction:

When printing was first brought into use, a multitude of copyists were of course immediately deprived of occupation; for it may be fairly reckoned, that one journeyman printer does the business of two hundred copyists. We may, therefore, conclude, that 199 out of 200 were thrown out of work. What followed? Why, in a little time, the greater facility of reading printed than written books, the low price to which books fell, the stimulus this invention gave to authorship, whether devoted to amusement or instruction, the combination, in short, of all these causes, operated so effectually as to set at work, in a very little time, more journeymen printers than there were formerly copyists. And if we could now calculate with precision, besides the number of journeymen printers, the total number of other industrious people that the press finds occupation for, whether as type-founders and moulders, paper-makers, carriers, compositors, bookbinders, booksellers, and the like, we should probably find, that the number of persons occupied in the manufacture of books is now 100 times what it was before the art of printing was invented. (Say, 1821, p. 41) (Note 7) 
Say saw economic progress as built on the actions and innovations of entrepreneurs responding to the actions and innovations of other entrepreneurs. To him, economic progress resulted from cascades of ideas, improvements, imitations and interactions rather than as something that sprang out of some sole entrepreneurial inventor's head like Athena from the head of Zeus. It is hard to see how his ideas could properly be presented in the context of "a static world of equilibrium". In truth, our concept of static equilibrium would in all likelihood have seemed outlandish to him. Sure, he believed in equilibrating forces in the sense that he believed entrepreneurs would act to reduce both gluts and shortages. But he did not envision static equilibrium situations in which there is no scope for innovation and no incentive for anyone to change anything. My best guess is that this notion, that Say's entrepreneur can be represented in a static equilibrium framework, is somehow tied to an acceptance of Keynes's straw man supply-creates-its-own-demand version of Say's Law (see Jonsson, 1995 and 1997) followed by the leap that if Say really believed in "Say's Law" then he must presciently have based this belief on 20th century Arrow-Debreu general equilibrium analysis.

\section{Conclusions}

The term entrepreneur is older than the most of the literature on entrepreneurship suggests. Moreover, before the introduction of this specific term into English, we had a number of different words which stressed various aspects of entrepreneurial behavior and function. Moreover, the term itself notwithstanding, both the pre-classical and the classical economics literature had a richness that we are likely to overlook if we are too focused on the use of any single word. Besides, the meaning of words tends to change over time, especially when they are used in different contexts in different period.

Certainly, the context of modern-day equilibrium-based economics frames the word entrepreneur differently than the context of classical economics did. Say and his followers amongst the classical economists had what amounts to a dialectical view of the entrepreneurial process and economic change. From a dialectical perspective, unending disruptive change is normal. There is no achieving a steady state because we constantly have innovations that disrupt the path towards anything that we could think of in such terms. What we have instead is an ongoing process of innovations that are brought on by new opportunities and competing interests derived from earlier innovations. The process is dialectical (from dialogue, etc., in the old Greek sense of it) in that new products and services will embody new arguments that will in turn call for counterarguments based both on threats to existing products and also based new opportunities derived from innovations. Note that this suggests a continuity of changes. New innovations build on what came before. To the extent that the entrepreneurial process generates creative destruction, this in itself creates new incentives to keep the entrepreneurial process going. Every new idea, product, and process embodies a challenge to be met with new ideas, products and processes. In this sense, the new often carries within it or embodies the seeds of its own obsolescence. Say understood and elaborated on all of this. The ubiquitous straw-man versions of Say, which fail to appreciate the subtle workings of his ideas, are based on reading him out of context.

\section{Acknowledgments}

The author would like to thank Richard van den Berg of Kingston University, Nicolas Theocarakis of Athens University and the participants in the Austrian Economics Forum at North Carolina State University for helpful comments.

\section{References}

Anonymous. (1662). Ichthyothera, or, The royal trade of fishing. London, 1662, The Making of the Modern World. Gale Document Number: U100187931.

Badeslade, T. (n. d.). The new cut canal, intended for improving the navigation of the city of Chester. Chester, The Making of the Modern World. Gale Document Number: U100725935.

Barreto, H. (1989). The Entrepreneur in Microeconomic Theory: Disappearance and Explanation. London, New York: Routledge.

Baumol, W. J. (1990). Entrepreneurship: Productive, Unproductive and Destructive. Journal of Political Economy, 98(5), 893-921. https://doi.org/10.1086/261712

Baumol, W. J. (2010). The Microtheory of Innovative Entrepreneurship. Kauffman Foundation Series on Innovation and Entrepreneurship.

Belcamp, J. V. (1651). Consilium \& votum pro ordinanda ac stabilienda Hibernia. London, The Making of the Modern World. Gale Document Number: U100153412.

Boileu, D. (1811). An introduction to the study of political economy. London: Cadell and Davies. The Making of 
the Modern World. Gale Document Number: U103053960

Bolton, R. (1637). A short and private discourse betweene Mr. Bolton and one M.S. concerning Usury. London, The Making of the Modern World. Gale Document Number: U100134757.

Bushell, T. (1642). A iust and true remonstrance of his Maiesties mines-royall in the principality of Wales. London, The Making of the Modern World. Gale Document Number: U107235062.

Cantillon, R. (1755). Essai sur la nature du commerce en général. London: F. Gyles, The Making of the Modern World. Gale Document Number: U100986440.

Cantillon, R. (1931). Essai sur la nature du commerce en general: Edited with an English Translation by Henry Higgs. London: Macmillan.

Cantillon, R. (2010). An Essay on Economic Theory: An English Translation of Richard Cantillon's Essai sur la Nature du Commerce en Général (Translated by C. Saucier). Ludwig von Mises Institute.

Chamberlen, P. (1649). The poore mans advocate, or, Englands Samaritan: Powring oyle and wyne into the wounds of the nation. London, The Making of the Modern World. Gale Document Number: U101467093.

Cotgrave, R. (1611). A Dictionarie of the French and English Tongves. London: Adam Islip (Google Books).

Darell, J. (1651). East-India-trade first discovered by the English. London, The Making of the Modern World. Gale Document Number: U100155667.

Dewar, M. (1966). The Authorship of the "Discourse of the Commonweal". Economic History Review, 19(2), 388-400. https://doi.org/10.2307/2592259

Drucker, P. F. (1985). Innovation and Entrepreneurship: Practice and Principles. New York: Harper \& Row.

Dufour, P. S. (1685). The manner of making coffee, tea, and chocolate as it is used in most parts of Europe, Asia, Africa, and America / newly done out of French and Spanish. London, The Making of the Modern World. Gale Document Number: U103863835.

Gorges, F. (1658). America painted to the life. London, The Making of the Modern World. Gale Document Number: U104066633.

Hartlib, S. (1655). The reformed common wealth of bees. London, The Making of the Modern World. Gale Document Number: U104930553

Hennequin, J. (1595). Le gvidon general des financiers, contenant la conseruation et interpretation des droicts sacrez et inalienables du Domaine du Roy et Coronne de France. Lyon, The Making of the Modern World. Gale Document Number: U100065064.

Higgs, H. (1891). Richard Cantillon. Economic Journal, 1(2), 262-291. https://doi.org/10.2307/2956249

Higgs, H. (1892). Cantillon's Place in Economics. Quarterly Journal of Economics, 6(4), 436-456. https://doi.org/10.2307/1882513

Howell, J. (1678). Epistolae Ho-Elianae: familiar letters, domestic and forren (5th ed.). London, The Making of the Modern World. Gale Document Number: U103862819.

Iversen, J., Jørgensen, R., \& Malchow-Møller, N. (2008). Defining and Measuring Entrepreneurship. Foundations and Trends in Entrepreneurship, 4(1), 1-63. https://doi.org/10.1561/0300000020

Jevons, W. S. (1881). Richard Cantillon and the Nationality of Political Economy. Contemporary Review, 39, 61-80.

Johnson, S. (1755). A dictionary of the English language. (In 2 volumes). London, The Making of the Modern Gale Document Number: U109812327.

Jonsson, P. O. (1995). On the Economics of Say and Keynes' Interpretation of Say's Law. Eastern Economic Journal, 21(2), 147-155.

Jonsson, P. O. (1996). Choice, Uncertainty, and Innovation: A New Look at Consumer Entrepreneurs. Journal of Private Enterprise, 11(2), 92-106.

Jonsson, P. O. (1997). On Gluts, Effective Demand and the True Meaning of Say's Law. Eastern Economic Journal, 23(2), 203-218.

Jonsson, P. O. (2009). The Economics of Spam and the Context and the Aftermath of the CAN-SPAM Act of 2003. International Journal of Liability and Scientific Enquiry, 2(1), 40-52. 
https://doi.org/10.1504/IJLSE.2009.021532

Jonsson, P. O. (2014). What's in a Name? On Language, Concept Formation, and the Definition Disputes in the Entrepreneurship Literature. Cultural Science, 7(1), 1-22.

Kirzner, I. M. (1997). Entrepreneurial discovery and the competitive market process: An Austrian approach. Journal of economic Literature, 35(1), 60-85.

Kirzner, I. M. (1999). Creativity and/or alertness: A reconsideration of the Schumpeterian entrepreneur. The Review of Austrian Economics, 11(1-2), 5-17. https://doi.org/10.1023/A:1007719905868

Landes, D. S., Mokyr, J. \& Baumol, W. J. eds. (2012). The Invention of Enterprise: Entrepreneurship from Ancient Mesopotamia to Modern Times. Princeton: Princeton University Press.

Malynes, G. (1656). Consuetudo: vel, lex mercatoria, or, the ancient lawmerchant. London, The Making of the Modern World. Gale Document Number: U100104455.

Mun, T. (1664). England's Treasure by Forraign Trade. London: Thomas Clark, The Making of the Modern World. Gale Document Number: U100191201.

Parker, H. (1642). The vintners answer to some scandalous phamphlets published, (as is supposed). by Richard Kilvert. London, 1642, The Making of the Modern World. Gale Document Number: U106189239.

Peneder, M. (2009). The Meaning of Entrepreneurship: A Modular Concept. Journal of Industry, Competition and Trade, 9(2), 77-99. https://doi.org/10.1007/s10842-009-0052-7

Petty, W. (1683). Another Essay in Political Arithmetick. London: Mark Pardoe, The Making of the Modern World. Gale Document Number: U100273945.

Plat, H. (1594). The jewellhouse of art and nature. London, The Making of the Modern World. Gale Document Number: U109736902.

Potter, W. (1650). The key of wealth: or, a new way, for improving of trade: lawfull, easie, safe and effectuall. London, The Making of the Modern World. Gale Document Number: U100152118.

Purser, W. (1634). Compound interest and annuities. London, 1634, The Making of the Modern World. Gale Document Number: U103754478

Ramsay, G. (1836). An essay on the distribution of wealth. Edinburgh, The Making of the Modern World. Gale Document Number: U109490655.

Robartes, F. (1613). The revenue of the gospel is tythes, due to the ministerie of the word, by that word. Cambridge, The Making of the Modern World. Gale Document Number: U108758727.

Say, J. B. (1803). Traité d'economie politique; ou, Simple exposition de la manière dont se forment, se distribuent et se consomment les richesses (2 volumes). Paris, The Making of the Modern World. Gale Document Number: U102823259.

Say, J. B. (1819). Traité d'economie politique; ou, Simple exposition de la manière dont se forment, se distribuent et se consomment les richesses; quatrième éd., corrigée et augmentée, a laquelle se trouve joint un épitome des principes fondamentaux de l'economie politique. Volume 1. 4th ed. Paris, 1819, The Making of the Modern World. Gale Document Number: U103515539.

Say, J. B. (1820). Lettres à M. Malthus, sur différens sujets d'économie politique, notamment sur les causes de la stagnation générale du commerce. Paris, The Making of the Modern World. Gale Document Number: U103563259.

Say, J. B. (1821). A treatise on political economy : or, The production, distribution, and consumption of wealth translated from the 4th ed. of the French by C.R. Prinsep. Volume 1. Boston, The Making of the Modern World. Gale Document Number: U104392631.

Say, J. B. (1821). Letters to Mr. Malthus on several subjects of political economy and on the cause of the stagnation of commerce : to which is added a catechism of political economy. (Translated by J. Richter). London, The Making of the Modern World. Gale Document Number: U104391851.

Say, J. B. (1821). Letters to Mr. Malthus on various subjects of political economy, particularly on the causes of the general stagnation of commerce. (Translator unknown). London, The Making of the Modern World. Gale Document Number: U104391851.

Schumpeter, J. A. (1954). History of Economic Analysis. New York: Oxford University Press. 
Smith, A. (1776). An inquiry into the nature and causes of the wealth of nations, 1. London, 1776. The Making of the Modern World. Gale Document Number: U101696886.

Smith, A. (1778-9). Recherches sur la nature et les causes de la richesse des nations. La Haye, The Making of the Modern World. Gale Document Number: U101782745.

Smith, A. (1801). An inquiry into the nature and causes of the wealth of nations, 1. Basil, 1801, The Making of the Modern World. Gale Document Number: U106616475.

Smith, S. (1661). A narrative of the royal fishings of Great Britain and Ireland, with busses for pickled herrings and barrel-cod, after the manner of the Hollanders. London, 1661. The Making of the Modern World. Gale Document Number: U108694853.

Stafford, W. (1581 [1751]). A compendious or briefe examination of certayne ordinary complaints of diuers of our countrymen in these our dayes. London, The Making of the Modern World. Gale Document Number: U100917199.

Violet, T. (1653). Mysteries and secrets of trade and mint-affairs. London, The Making of the Modern World. Gale Document Number: U100162082.

Webster Online Dictionary. (2015). $\quad$ Retrieved from http://www.websters-online-dictionary.org/definitions/entrepreneur

White, J. (1630). The planters plea: Or the grovnds of plantations examined, and vsuall objections answered. London, The Making of the Modern World. Gale Document Number: U101466224.

\section{Notes}

Note 1. "Tous les autres sont Entrepreneurs, soit qu'ils s'établissent avec un fond pour conduire leur entreprise, soit qu'ils soient Entrepreneurs de leur propre travail sans aucuns fonds, et ils peu vent être considerés comme vivant à l'incertain; les Gueux même et les Voleurs sont des Entrepreneurs de cette classe." (Cantillon, 1755, pp. 71-72)

Note 2. "Je révère Adam Smith: il est mon maître. Lorsque je fis les premiers pas dans l'économie politique ... il me montra la bonne route." (Say, 1820, p. 42)

Note 3. "Un homme qui cultive à ses propres frais le jardin qui lui appartient, possède, le capital et l'industrie. Il fait, lui seul, le benefice du propriétaire foncier, du capitaliste et l'homme industrieux." (Say, 1819, p. 37)

Note 4. "J'ai dit que l'agriculteur, le manufactutier, le négociant profitaient des connaissances acquises, et les appliquaient aux besoines des hommes"(Say, 1819, p. 48)

Note 5. From: "Les sciences ne suffisent, donc pas à l'avancement des arts, il faut de plus des expériences plus ou moins hasardeuses, dont le succès ne dédommage pas toujours de ce qu'elles on coûté; la concurrence ne tarde pas à modérer les benefices de l'entrepreneur" (Say, 1819, p. 48)

Note 6. From: "Le profit de l'entrepreneur au compte duquel l'opération a été faite, en faisant abstraction de l'intérêt du capital qu'il peut y avoir employé, représente le salarie de son temps et de son talent, c'est-à-dire ses propres services productifs à lui-même. Si sa capacitê a été grande et ses calculs bien faits, son profit est considérable. Si au lieu de talent, il a mis de l'impéritie dans son affaire, il a pu ne rien gagner, il a pu perdre. C'est lentrepreneur que tous les risques atteignent; mais c'est lui, par contre, qui profite de toutes les chances favourables." (Say, 1820, pp. 28-29)

Note 7. From Say's discussion on the introduction of printing (l'imprimerie): “Au moment où elle fut employée, une foule de copistes dûrent rester inoccupés; can on peut estimer qu'un seul ouvrier imprimeur fait autant debesogne que deux cents copistes. Il faut donc croire que 199 ouvriers sur 20020 restèrent sans ouvrage. Hé bien, la facilité de lire les ouvrages manuscrits, le bas prix auquel les livres tombèrent, l'encouragement que cette invention donna aux auteurs pour en composer en bien plus grande nombre, soit d'instruction, soit d'amusement; toute ces causes firent qu'au bout de trèspeu de temps, il y eut plus d'ouvriers imprimeurs employés qu'il n'y avait auparavant de copistes. Et si à present on pouvat calculer exactement, non-seulement le nombre des ouvriers imprimeurs, mais encore des industrieux que l'imprimerie fait travailler, comme graveurs de poinçons, foundeurs de caractères, fabricans de papier, voituriers, correcteurs, relieurs, libraires, on trouverait peut-être que le nombre des personnes occupées par la fabrication des livres est cent fois plus grand que celui qu'elle occupait avant l'invention de l'imprimerie." (Say, 1820, pp. 58-59) 


\section{Copyrights}

Copyright for this article is retained by the author(s), with first publication rights granted to the journal.

This is an open-access article distributed under the terms and conditions of the Creative Commons Attribution license (http://creativecommons.org/licenses/by/4.0/). 